\title{
IPTEKS PENGELOLAAN RISIKO KEPATUHAN PADA PT. BANK SULUTGO
}

\author{
Gracela Gloria Rawis ${ }^{1}$, Harijanto Sabijono ${ }^{2}$ \\ ${ }^{1,2}$ Jurusan Akuntansi, Fakultas Ekonomi dan Bisnis, Universitas Sam Ratulangi, Jl. Kampus Bahu, Manado, \\ 95115, Indonesia
}

Email : gracelagloria@gmail.com

\begin{abstract}
ABSRACT
In running a business, the company cannot be separated from the risks that can threaten the company. Risks that arise require attention and improvement so that a business can survive and compete in the business world. There are various kinds of risks that arise especially at banks, usually in the form of reputation, operational, credit, market, strategic, legal, liquidity and compliance risks. From these risks, Bank SulutGo feels the need to conduct monitoring and evaluation to minimize the existing risks. This journal aims to discuss compliance risk management implemented by SulutGo Bank. By using the implementation method based on OJK Regulation Number 18 / POJK.03 / 2016 on March 16, 2016. This regulation contains the implementation of risk management for commercial banks. Based on the methods available, several steps need to be applied. This journal raises four steps, namely: identifying, measuring, monitoring, and finally mitigating. These four steps need to be done to achieve risk management that is right on target.

Keywords: risk management, compliance function, identification, measurement, monitoring, mitigation,
\end{abstract}

\section{PENDAHULUAN}

Di zaman yang semakin maju ini, bank bukanlah suatu hal yang asing bagi masyarakat. Karena dari berbagai kalangan peran bank cukup dominan dalan membantu masyarakat dalam berbagai aktivitas. Kemudahan yang ditawarkan oleh bank mampu menarik perhatian masyarakat untuk menggunakan produk ataupun jasa yang ditawarkan oleh bank. Bank itu sendiri merupakan suatu badan usaha yang menyalurkan dana dari pihak yang memiliki dana ke pihak yang membutuhkan dana. Dari aktivitas yang dilakukan oleh bank tidak dapat dipungkiri akan muncul risiko-risiko yang dapat mengancam operasional suatu bank. Ada delapan risiko yang dapat mempengaruhi pihak bank yaitu; resiko kredit, resiko pasar, resiko likuiditas, resiko operasional, resiko hukum, resiko stratejik, resiko kepatuhan, dan resiko reputasi. Dengan adanya resiko-resiko tersebut, pihak bank mendapatkan pekerjaan ekstra untuk lebih memperhatikan resiko-resiko yang ada. Pihak bank perlu melakukan pemantauan dan evaluasi terhadap aktivitas yang dijalankan oleh bank agar dapat meminimalisir resiko yang dapat terjadi.

Hal yang sama berlaku pada pihak Bank SulutGo. Bank SulutGo melakukan usaha untuk meminimalisir resiko dengan melakukan pengelolaan manajemen resiko. Maka daripada itu Pihak Bank SulutGo membentuk suatu komite yang memiliki tugas dan tanggung jawab dalam mengelola resiko, juga membuat kebijakan serta strategi agar pihak bank dapat memastikan tidak terjadi penyimpangan pada saat melakukan aktivitas bank. Adanya pemantauan dan penjagaan kepatuhan bank juga merupakan bagian dari implementasi manajemen resiko. Selain daripada itu diperlukan juga pengkajian kembali yang dilakukan secara berkala terhadap manajemen resiko. Hal-hal tersebut diupayakan oleh bank agar perusahaan mampu bertahan dan bersaing dengan para kompetitor yang semakin hari semakin banyak. Seiring berjalannya waktu pihak kempetitor mengalami peningkatan 
jumlah, sehingga pihak Bank SulutGo perlu melakukan usaha ekstra, untuk dapat bersaing dan dapat mengikuti perkembangan-perkembangan yang ada.

\section{TINJAUAN PUSTAKA}

Manajemen Risiko. Manajemen Resiko terdiri dari manajemen dan resiko. Manajemen itu sendiri dapat diartikan sebagai suatu tindakan atau upaya yang dimaksudkan sebagai sarana pencapaian tujuan dengan memakai sumber daya secara tepat melalui koordinasi, arahan dan pemantauan. Sedangkan resiko merupakan sesuatu yang belum pasti berupa kemungkinan atau estimasi terjadinya kerugian. Dapat disimpulkan manajemen resiko adalah suatu kegiatan identifikasi, pemantauan, pengukuran, dan pengendali kemungkinan kerugian yang terjadi.

Fungsi Kepatuhan. Berdasarkan Peraturan Bank Indonesia Nomor 13/2/PBI/2011 mengenai Penerapan Fumgsi Kepatuhan Bank Umum yang mengatur fungsi kepatuhan. Fungsi Keatuhan yang dimaksud berupa rangkaian upaya dengan kata lain beberapa langkah yang memiliki sifat peventif untuk meyakinkan bahwa aturan-aturan, system dan lagkahlangkah yang dilakukan pihak bank sudah berdasarkan ketentuan Bank Indonesia, dan peraturan yang berlaku.

\section{METODE DAN TEKNIK PERNERAPAN IPTEKS}

\subsection{Metode Penerapan Ipteks}

Implementansi yang diterapkan berupa manajemen resiko yang mengacu pada Peraturan OJK Nomor 18/POJK.03/2016 juga surat edaran otoritas jasa keuangan nomor 34/SEOJK.03/2016. Di mana pada bab 1 mengenai ketentuan umum dicantumkan resikoresiko yang ada, yaitu:

1. Resiko Kredit

2. Resiko Pasar

3. Resiko Likuiditas

4. Resiko Opersional

5. Resiko Kepatuhan

6. Resiko Hukum

7. Resiko Reputasi

8. Resiko Stratejik

\subsection{Tenik Penerapan Ipteks}

Dalam penerapan ipteks manajemen resiko terdiri dari :

1. Mengidentifikasi resiko

2. Mengukur resiko

3. Memantau resiko

4. Melakukan metigasi resiko

\section{PEMBAHASAN}

\subsection{Gambaran Objek Penerapan Ipteks}

PT Bank SulutGo berdiri dengan nama awal Bank Pembangunan Daerah Sulawsi Utara berdiri dengan berlandaskan Akte Nomor 80 pada tanggal 17-03-1961 oleh notaris dari Jakarta. Hal ini masih mengalami perubahan sebanyak dua kali hingga pada akhirnya disahkan oleh Menteri Kehakiman RI yang ditetapkan dalam No.J.A.5/109/6 pada tanggal 13-10-1961. Pada tahun 1999 Bank Pembangunan Daerah Sulawesi Utara mengalami perubahan bentuk badan hukum dari Perusahaan Daerah menjadi Perseroan Terbatas hal ini dilandasi oleh UU No.13 tahun 1964. Kelanjutan dari badan hukum yang berubah menjdi Perseroan Terbatas maka pendirian bank dilaksanakan dengan Akte No. 7 pada taggal 14-051999 dengan menggunakan notaries manado, menteri kehakiman RI mengesahkan dengan 
Keputusan No. C-8296.HT.01.01.TH'99 kemudian diumumkan dalam berita negara RI NO. 63 tanggal 06-08-1999. Perubahan bentuk hukum adalah keharusa sebagai syarat program rekapitalisasi perbankan. Namun Bank Sulut Go memisahkan diri rekapitalisasi perbankan sehingga berdampak pada perubahan anggaran dasar, dimana kepemilikan saham terjadi peningkatan modal dasar menjadi dua ratus miliar. Hal ini disitujui oleh Mneteri Hukum dan HAM pada tanggal 23-08-2006, kemudian pada tanggal 30-06-2008 Bank SulutGo meningkatkan modal dasar menjadi tiga ratus miliar. Hal ini merupakan suatu keputusan yang didapat pada rapat umum pemegang saham berdasarkan Akte notaris No. 220 tanggal 30-06-2008. PT Bank SulutGo masih melakukan upaya dengan meningkatkan modal dasar menjadi lima ratus miliar yang tercantum dalam Akte notaris No. 67 pada tanggal 12-062009, kemudian disetujui oleh Mneteri Hukum dan HAM. Upaya untuk meningkatkan modal dasar masih berlanjut pada 28-09-2012 sebesar satu triliun menurut Akte notaris No. 6 pada 01-10-2012 yang disetujui oleh Menteri Hukum dan HAM. PT Bank Pembangunan Daerah Sulawesi Utara Gorontalo meningkatkan modal dasar menjadi satu setengah triliun pada tahun 2015 yang telah disetujui oleh Menteri Hukum dan HAM. PT Bank SulutGo merupakan bank pembangunan daerah yang menjalankan usahanya dalam bidang perbankan dan jasa.

Manajemen Resiko. Mengacu pada Peraturan OJK No. 18/POJK.03/2016 juga Surat Edaran OJK No. 34/SEOJK.03/2016 mengenai Penerapan Manajemen Risiko Bagi Bank Umum. Pada Bab 2 Pasal 2 ayat (2) Penerapan Manajemen Resiko meliputi:

a. Direksi dan Dewan Komisaris secara aktiv melakukan pengawasan.

b. Ketentuan yang memadai dan Penetapan batas resiko melalui prosedur manajemen resiko;

c. Proses megidentifikasi, mengukur, memantau, dan mengendalikan resiko.

d. Keseluruhan sistem pengendalian internal.

Resiko yang dimaksud dalam Pasal 4 antara lain:

a. Resiko Kredit merupakan dampak dari gagalnya pihak eksternal dalam melakukan transaksi juga dalam pemenuhan kewajiban sebagai pihak yang bersangkutan, oleh karena itu pihak bank perlu memperketat proedur pemeberian pinjaman agar mengurangi resiko terjadinya kredit macet yang merugikan pihak bank.

b. Resiko Pasar merupakan resiko yag berdampak pada neraca dan rek administrasi derivatif yang penyebabnya adalah perubahan secara menyeluruh suatu keadaan pasar contohnya perubahan kurs, suku bunga.dana pihak ketiga.

c. Resiko Likuiditas nerupakan resiko yang mirip dengan resiko kredit namun bedanya terletak pada pihak yang gagal melaksanakan kewajibannya. Resiko likuiditas merupakan kegagalan dari pihak itu sendiri atau tidak memanfaatkan asset yang ada yang seharusnya meberikan keuntungan bagi pihak bank.

d. Resiko Operasional merupakan dampak dari faktor internal dan eksternal. Dimana faktor internal mencakup kekuatan dan kelemahan perusahaan, dimana kelemahan dapat menjadi resiko jika pihak bank tidak memberikan respon peningkatan atau perbaikan kelemahan dari pihak bank itu sendiri disisi lain kekuatan yang dimiliki jika tidak dimaskimalkan maka resiko yang ada yaitu hasil yang didaptkan tidak optimal, sedangkan faktor eksternal terdiri dari peluang dan ancaman dimana peluang-peluang yang ada harus dipergunaka dengan semestinya. Kemudian ancaman yang ada perlu dihindari agar meminimalisir resiko yang ditimbulkan. Menghindari ancaman dapat dilakukan dengan memperbaki kelemahan, memaksimalkan kekuatan, serta mempergunakan peluang yang tersedia.

e. Resiko Kepatuhan adalah resiko yang muncul akibat tidak mampunya menjalankan atau melakukan prosedur yang berlaku yang sudah disepakati serta yang telah dicantumkan dalam suatu surat keputusan atau dalam buku yang memuat aturan-aturan yang ada. 
f. Resiko Hukum adalah resiko yang muncul akibat adanya kekuatan hukum yang mendesak pihak bank yang muncul lewat aktivitas perusahan yang mengakibatkan perusahaan tidak mampu untuk beradaptasi dengan masalah yang ada sehingga muncullah resiko hukum.

g. Resiko Reputasi adalah resiko yang muncul dari adanya pemikiran ataupun opini negatif dari pihak pemegang saham yang membuat mereka tidak mempercayai lagi bank tersebut yang mengakibatkan menurunya kualitas bank.

h. Resiko Stratejik adalah resiko yang dihasilkan dari gagalnya pihak bank dalam menentukan langkah bisnis ataupun tidak mampu menjalankannya secara tepat sehingga tidak mendapatkan hasil yang optimal seperti yang diharpkan. Sehingga memperlambat dalam usaha pencapaian tujuan.

\subsection{Pembahasan}

1. Identifikasi resiko. Identifikasi resiko merupakan tahap awal yang perlu dilakukan sebelum mengukur resiko. Perlunya mengidentifikasi resiko agar kita mampu memahami karakter-karakter resiko yang ada, hal ini bermanfaat agar mampu menentukan cara yang tapat dalam pengelolaan resiko. Setelah mempelajari karakteristik selanjutnya kita perlu memprioritaskan resiko agar kita dapat menentukan tinggi rendahnya resiko terhadap kinerja bank. Setelah menntukan prioritas resiko bank, kita menentukan mana resiko yang memberkan pengaruh besar bagi bank. Dalam mengidentifikasi perlu diketahui sumber resiko yang bisa dilihat dari lingkungan fisik, social, politik, legal, operasional serta ekonomi.

2. Pengukuran resiko. Pengukuran resiko kita mampu menilai seberapa tinggi rendahnya resiko yang harus dihadapi oleh pihak bank sehigga kita dapat memperkirakan akibat atau dampak dari resiko yang mempengaruhi kinerja bank. Pengukuran ini bisa melalui kuantifikasi resiko.

3. Pemantauan resiko. Pemantauan resiko merupakan kegiatan yang meninjau dan diikuti oleh tindakan agar meyakinkanrencana atau strategi yang diimplemntasikan memberikan perubahan dari resiko yang ada.

4. Mitigasi Resiko merupakan tahapan untuk mengurangi resiko yang dimiliki dengan menggunakan peningkatan kualitas dalam penerapan manajemen resiko yang mencakup tata kelola resiko, susunan manajemen resiko, tahap-tahap manajmen resiko, dan sisntem informasi yang memadai juga sistem pengendalian internal yang memadai.

\section{KESIMPULAN DAN SARAN}

\subsection{Kesimpulan}

Dalam mengelola resiko kepatuhan perlu dilakukan pengunaan metode manajemen resiko. Hal ini membantu untuk menganalisis resiko-resiko yang ada. Penetapan metode perlu diiringi dengan langkah-langkah yang harus diterapkan yaitu mengidentifikasi resiko, mengukur resiko, melakukan pemantauan resiko, dan melakukan metigasi resiko. Langkahlangkah ini membantu pihak bank untuk mengurangi resiko yang ada dalam menjalankan aktivitas bank. Dampak dari meminimalisir resiko tentunya membantu pihak bank untuk mencapai tujuan yang telah ditentukan. Fungsi kepatuhan juga berperan penting dalam pengelolaan manajemen resiko. Hal ini dapat dilihat dari fungsi yang diberikan dengan memastikan bahwa aktivitas-aktivitas bank berjalan dengan semestinya sesuai dengan ketentuan-ketentuan yang berlaku.

\subsection{Saran}

Resiko-resiko yang ada tidak dapat dihilangkan namun dapat diminimalisir. Karena semakin kompleksnya produk yang ada serta kegiatan bank yang semakin banyak memberikan dampak bagi pihak bank memiliki resiko yang semakin meningkat. Resikoresiko ini perlu diikutsertakan dengan mengimbangi kulitas penerapan manajemen yang baik 
dan memadai agar kualitas pnerapan manajemen resiko mampu menopang secara efektif dalam mengawasi resiko yang ada.

\section{DAFTAR PUSTAKA}

PT. Bank Sulawesi Utara Gorontalo. 2017. Annual Report.

Peraturan BI Nomor 13/2/PBI/2011 tentang Pelaksanaan Fungsi Kepatuhan

Peraturan OJK Nomor 18/POJK.03/2016 tanggal 16 Maret 2016 tentang Penerapan Manajemen Risiko Bagi Bank Umum

Surat Edaran Otoritas Jasa Keuangan Nomor 34 /SEOJK.03/2016 tanggal 1 September 2016

Riduan Karim. 2004. Prinsip-Prinsip Manajemen Risiko. Jurnal Iqtisad

Tengor Rifangga C. T., Murni Sri., dan Moniharapon Silcyljeova. 2015. Penerapan Manajemen Risiko Untuk Meminimalisir Risiko Kredit Macet Pada PT. Bank SulutGo. Jurnal Emba

Watopa Elviliana Y., Murni Sri., dan Saerang Ivone S., 2017. Analisis Penerapan Pengelolaan Risiko Operasional Pada PT. Bank SulutGo. Jurnal Emba

Utomo Andy Prasetyo. 2012. Penggunaan Framework Manajemen Risiko Sistem Informasi Untuk Penganan Bencana Alam Banjir. Jurnal Umk

Yushita Amanita Novi. 2008. Implementasi Risk Management Pada Industri Perbankan Nasional. Jurnal Pendidikan Akuntansi Indonesia

Sari Lisa Kartika. 2012. Penerapan Manajemen Risiko Pada Perbankan Di Indonesia. The Indian Economic Journal

Sirait Juanda Evan., Patricia Maria., Sipahutar Steven Fitzgerald., dan Seto Aryo., 2008. Manajemen Risiko Reputasi PT Bank UOB Indonesia. Jurnal CCSEI

Aditya Oka., Naomi Prima., 2017. Penerapan Manajemen Risiko Perusahaan dan Nilai Perusahaan di Sektor Konstruksi dan Properti. Jurnal Bisnis dan Manajemen 